\title{
High-resolution ice nucleation spectra of sea-ice bacteria: implications for cloud formation and life in frozen environments
}

\author{
K. Junge ${ }^{1}$ and B. D. Swanson ${ }^{2}$ \\ ${ }^{1}$ University of Washington, Applied Physics Laboratory - Polar Science Center, Mail-box: 355640, Henderson Hall 1013 NE \\ 40th St, Seattle, WA 98195, USA \\ ${ }^{2}$ University of Washington, Earth and Space Sciences, Box 351310, Seattle, WA 98195, USA and Laucks Foundation Inc. \\ Bellevue, WA 98004, USA
}

Received: 17 September 2007 - Published in Biogeosciences Discuss.: 19 November 2007

Revised: 17 March 2008 - Accepted: 24 April 2008 - Published: 22 May 2008

\begin{abstract}
Even though studies of Arctic ice forming particles suggest that a bacterial or viral source derived from open leads could be important for ice formation in Arctic clouds (Bigg and Leck, 2001), the ice nucleation potential of most polar marine psychrophiles or viruses has not been examined under conditions more closely resembling those in the atmosphere. In this paper, we examined the ice nucleation activity (INA) of several representative Arctic and Antarctic sea-ice bacterial isolates and a polar Colwellia phage virus. Highresolution ice nucleation spectra were obtained for droplets containing bacterial cells or virus particles using a free-fall freezing tube technique. The fraction of frozen droplets at a particular droplet temperature was determined by measuring the depolarized light scattering intensity from solution droplets in free-fall. Our experiments revealed that all sea-ice isolates and the virus nucleated ice at temperatures very close to the homogeneous nucleation temperature for the nucleation medium - which for artificial seawater was $42.2 \pm 0.3^{\circ} \mathrm{C}$. Our results suggest that immersion freezing of these marine psychro-active bacteria and viruses would not be important for heterogeneous ice nucleation processes in polar clouds or to the formation of sea ice. These results also suggested that avoidance of ice formation in close proximity to cell surfaces might be one of the cold-adaptation and survival strategies for sea-ice bacteria. The fact that INA occurs at such low temperature could constitute one factor that explains the persistence of metabolic activities at temperatures far below the freezing point of seawater.
\end{abstract}

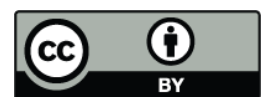

Correspondence to: K. Junge (kjunge@apl.washington.edu)

\section{Introduction}

Psychrophilic (including both steno- and europsychrophilic, Caviccioli, 2006) bacteria are capable of growing at temperatures at least as low as $-1{ }^{\circ} \mathrm{C}$ and are important constituents of polar ecosystems. These bacteria have successfully evolved genotypic and phenotypic features to surmount the negative effects of low temperatures on cell functions thereby enabling them to remain active in extreme low temperature environments (Deming, 2002; Caviccioli, 2006; D'Amiko et al., 2006; Junge et al., 2006). In this paper, we investigate the ice initiation potential of several representative sea-ice bacteria isolates to assess the role that marine psychro-active bacteria could play in the formation of sea ice and ice in polar clouds. These results may also provide a basis for exploring possible mechanisms for psychrophilic adaptation to ice crystal formation.

The climate of the earth is very sensitive to the microphysical, radiative and chemical properties of glaciated clouds (Houghton et al., 2001; Vogelmann and Ackerman, 1995). Accurate climate modeling requires that the entire process from particle formation to cloud drop- and ice nucleation be known (Bigg and Leck, 2001). Studies of Arctic clouds have suggested that marine bacteria and other particles of biological origin derived from open leads within the sea-ice cover could be important for ice formation in these clouds (Bigg and Leck, 2001), but few experiments have measured the ice nucleation activity of polar marine bacteria (Parker et al., 1985).

Bacteria found trapped within sea-ice have been suggested to be involved in its nucleation (summarized by Sullivan, 1985). Sea ice is known to be of great importance to polar and oceanic climate (Eicken and Lemke, 2001) but the origin, composition, and number of ice nuclei that may initiate the formation of sea ice are still not well understood. At the beginning of winter marine psychrophilic INA (i.e. ice

Published by Copernicus Publications on behalf of the European Geosciences Union. 


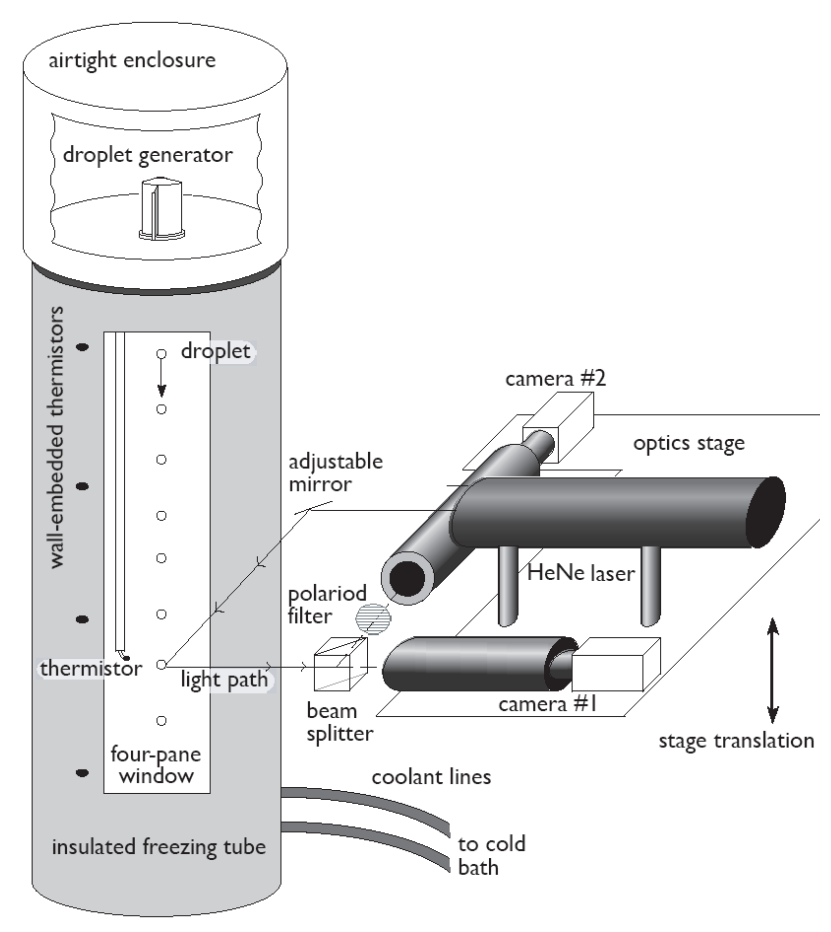

Fig. 1. Schematic representation of freezing tube apparatus (adapted from Larson and Swanson, 2006).

nucleation active) bacteria could provide such a source when lifted into the cold air in regions of active ocean-air transfer (Leck and Bigg, 1999) where they could cause ice formation within their lofted water droplet (through immersion freezing processes; Pruppacher and Klett, 1997). Then, when these crystals fall back down into the water they would initiate the formation of sea ice (opposed to causing growth of new ice crystals from within the water column). To date, there is some evidence for such an involvement of sea-ice bacteria in its formation (Sullivan et al., 1985), including one report of an unidentified sea-ice bacterial strain being ice nucleation active at temperatures between -2.0 and $-3.5^{\circ} \mathrm{C}$ (Parker et al., 1985). Pseudomonas antarctica, isolated from Antarctic soil, has also been found to possess INA ( $T_{f}$, defined as the freezing temperature where $50 \%$ of droplets are frozen, was $\sim-4^{\circ} \mathrm{C}$ under some incubation conditions, Obota et al., 1999). However, none of these studies were performed using a substrate-free methodology thereby more closely resembling conditions in the atmosphere nor were multiple strains of representative groups of sea-ice bacteria commonly found in these regions tested.

\section{Experimental method}

\subsection{Ice nucleation activity assay}

We used a freezing-tube technique (described more fully in Wood et al., 2002; Larson and Swanson, 2006; Swanson, 2008) to assay the freezing spectra of 17 isolates of marine psychro-active bacteria and virus particles. The freezing tube consisted of a vertical hollow brass cylinder with long vertical multi-pane windows on opposing sides for illumination and observation of the drops as they fell. A droplet-ondemand droplet generator was mounted co-axially on top of the tube with a vertical temperature gradient along the tube axis maintained by circulating low-temperature methanol through copper coils attached to the tube base. Droplets were ejected from the droplet-on-demand droplet generator and the droplets cooled as they fell down the tube axis (see Fig. 1).

The phase of the droplets (whether they are liquid or solid) at various heights (temperatures) in the tube was determined using a depolarized laser light scattering technique consisting of two video cameras with telemicroscopic lenses, a polarizing filter, and a beam-splitter mounted on a metal stage which, after alignment, may be translated up and down along the freezing tube's vertical axis (see Fig. 1). To determine the fraction of frozen droplets at a particular temperature, we positioned the phase detection system such that a polarized $\mathrm{HeNe}$ laser beam intersected the droplet stream at the height of interest. Using the two cameras (one without and one with a polarizer) viewing the droplet stream through the beam-splitter, we obtained streak-images of both the total, TLS, and depolarized, DLS, light scattered from each falling droplet. We used the fact that light scattered from liquid droplets remains polarized in the laser's original plane of polarization, whereas some backscattered light from frozen droplets will be depolarized due to droplet asphericity, cracks, bumps, surface roughness and birefringence. At a particular height in the freezing tube it was usually evident when the majority of droplets are liquid or frozen by simply looking at the video screen to see whether streaks could be seen only in the TSL image (liquid) or in both the TSL and DSL images (solid). Frozen fraction curves, $\mathrm{F}(\mathrm{T})$, (the fraction of droplets frozen at temperature $T$ ) were measured by translating the phase detection system (initially down to where $100 \%$ of the droplets are frozen) and then making measurements at intervals between $100 \%$ and $0 \%$ frozen fraction. At each temperature (height) about 100 to 400 images of droplet streaks were captured on video tape. We later analyzed each streak image by first subtracting the background intensity and then calculating the ratio DLS/TLS for each droplet. Those particles with DLS/TLS above some threshold value (typically about $7 \%$ of full-scale intensity) were defined to be frozen and those below that threshold, liquid. We set this threshold signal by comparing the various data sets and selecting a value that required the droplets to be 
all liquid at high temperature and all solid at temperatures far below the nucleation temperature (essentially at the lowest temperatures at the bottom of the freezing tube). On average DLS/TLS measurements were made for about 1000 droplets for a single $\mathrm{F}(\mathrm{T})$. Droplets (typically of $60 \mu \mathrm{m}$ in diameter) were emitted from the droplet generator at a rate of about $5 \mathrm{~Hz}$ (to avoid droplet-droplet interactions).

For each data run, the appropriate concentration of bacterial solution was injected into a new (and flushed with HPLC-grade water) droplet generator cartridge and immediately placed atop the freezing tube inside a sealed airtight enclosure. The enclosure and freezing tube were then purged of aerosol-laden room air using dry nitrogen gas thus reducing to near-zero the potential problem of an occasional influx of aerosol particles inducing droplet freezing through contact nucleation, especially at lower temperatures. Freezing tube temperatures were regularly recorded via computer using thermistors embedded in the cylinder walls and a thermistor attached to the bottom of a movable glass rod which could be positioned at any level vertically in the air within a few mm of the droplet stream. Typically, the wall temperature changed no more than a few hundredths of a degree every hour. The droplet temperature at varying heights in the droplet stream (where 0 to $100 \%$ of the droplets froze) was determined with the glass-rod thermistor. Further discussion of the analysis and experimental details can be found in previous publications (Wood et al. 2002; Larson and Swanson, 2005; Swanson, 2008).

\subsection{Sample preparation}

All bacterial strains tested for INA are listed in Table 1. The Arctic sea-ice bacterial strains were isolated from icecore samples collected during the Arctic West Summer 1996 (AWS96) cruise of the USCGC icebreaker "Polar Sea" into the Chukchi Sea (Table 1; Junge et al., 2002). C. psychrerythraea str. $34 \mathrm{H}$ was isolated from Arctic shelf sediments (Huston et al., 2000). Planococcus mcmeekenii str. S23F1 was isolated from Antarctic sea ice (Junge et al., 1998). Polar bacterial cultures were grown at $-1^{\circ} \mathrm{C}$ for 14 days (to late exponential growth) in half-strength Marine 2216 broth (DIFCO laboratories, Detroit, MI). Bacterial cells were then centrifuged at $1500 \times \mathrm{g}$ for $5 \mathrm{~min}$, washed twice in artificial seawater (ASW; for 11 of solution: $24 \mathrm{~g} \mathrm{NaCl}$, $0.7 \mathrm{~g} \mathrm{KCl}, 5.3 \mathrm{~g} \mathrm{MgCl}_{2} 6 \mathrm{H}_{2} \mathrm{O}, 7.0 \mathrm{~g} \mathrm{MgSO}_{4} 7 \mathrm{H}_{2} \mathrm{O}$, and $1.3 \mathrm{~g}$ TAPSO buffer), and after the final centrifugation step were re-suspended into artificial seawater to yield a final optical density at $600 \mathrm{~nm}$ (OD) of 0.5 . The cold-active Colwellia phage V-9 virus was kindly provided by Llyd Wells (Wells and Deming, 2006) at a concentration of approximately $10^{9}$ virus particles $\times \mathrm{ml}^{-1}$ in phage lysis buffer $(0.1 \mathrm{M} \mathrm{NaCl}$, $50 \mathrm{mM}$ Tris- $\mathrm{HCl} \mathrm{pH} 8.0,8 \mathrm{mM} \mathrm{MgSO}_{4}, 2 \mathrm{mM} \mathrm{CaCl}_{2}$ and $5 \%$ glycerol). Cultures of Pseudomonas syringae str. R31 were kindly provided by Steve Lindow's laboratory. Fresh cultures of Pseudomonas syringae str. R 31 were grown at room

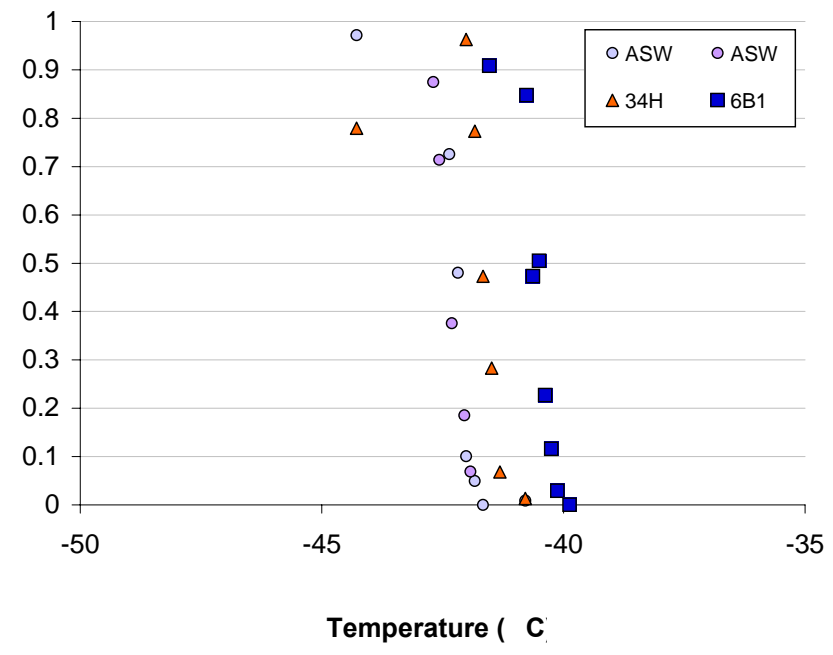

Fig. 2. Representative freezing spectra for polar bacterial islates Colwellia psychrerythraea str. $34 \mathrm{H}$ (triangles), sea-ice strain 6B1 (squares) and ASW (circles).

temperature for 3 days on Nutrient Agar plates. Cells were then harvested from plates, suspended in sterile distilled water, centrifuged at $1500 \times \mathrm{g}$ for $5 \mathrm{~min}$, washed twice in sterile distilled water and after the final centrifugation step were resuspended into distilled water or ASW to yield a final optical density at $600 \mathrm{~nm}$ of 2.0 .

Generally, ice nucleation tests were performed by adjusting the optical density of polar bacterial suspensions in sterile artificial seawater at $600 \mathrm{~nm}$ to 0.5 . The temperaturedependent freezing rates were then determined from each isolate, the virus preparation and artificial seawater (ASW). We used droplets of $0.10 \mathrm{nl}$ volume. To ensure that each droplet contained at least one bacterium at the optical density used, we determined the concentration of bacterial cells in our ASW suspensions for one of the isolates (Colwellia psychrerythraea str. $34 \mathrm{H}$ ) by counting the number of bacteria in collections of frozen droplets emitted from the droplet generator (see below) using standard epifluorescence microscopy and the DNA-specific stain 4',6'-diamidino-2-phenylindole 2HCl (DAPI), essentially as described by Junge et al. (2002). Determinations of bacterial concentration in collections of ejected droplets revealed that 3 to 5 bacteria were present in each droplet thus confirming that enough potential nuclei were present to facilitate ice nucleation.

\section{Results and discussion}

High-resolution ice nucleation spectra (INA) of selected seaice bacterial isolates that were representatives for most of the major known groups of sea-ice bacteria (both of Antarctic and Arctic origin) that we tested are shown in Figs. 2 and 3 in comparison to the artificial seawater (ASW) nucleation medium. The freezing temperature, $T_{f}$, was defined to be the 
Table 1. List of sea-ice and other bacterial isolates tested for INA, their closest relatives, habitat and $T_{f}$-defined as the temperature at which $50 \%$ of the droplets are frozen.

\begin{tabular}{|c|c|c|c|c|}
\hline Isolate & Species or closest relative & Phylum & Habitat & $T_{f}^{*}$ \\
\hline $34 \mathrm{H}$ & Colwellia psychrerethraea str. $34 \mathrm{H}$ & $\gamma$-Proteobacteria & Arctic sediment and sea ice, Antarctic sea ice & $-42.0 \pm 0.5$ \\
\hline $6 \mathrm{M} 3$ & Colwellia sp. IC169 & $\gamma$-Proteobacteria & Arctic and Antarctic sea ice & $-40.9 \pm 0.5$ \\
\hline $4 \mathrm{U} 2$ & Gas-vacuolate strain $214^{\mathrm{b}}$ & $\gamma$-Proteobacteria & Arctic sea ice & $-40.7 \pm 0.5$ \\
\hline $6 \mathrm{M} 4$ & Gas-vacuolate strain $214^{\mathrm{b}}$ & $\gamma$-Proteobacteria & Arctic sea ice & $-40.4 \pm 0.2$ \\
\hline 6B1 & Gas-vacuolate strain $214^{\mathrm{b}}$ & $\gamma$-Proteobacteria & Arctic sea ice & $-41.1 \pm 0.9$ \\
\hline $7 \mathrm{M} 1$ & Pseudoalteromonas antarctica str. IC 013 & $\gamma$-Proteobacteria & Arctic and Antarctic sea ice & $-41.4 \pm 0.6$ \\
\hline $4 \mathrm{M} 2$ & Pseudoalteromonas antarctica str. IC 013 & $\gamma$-Proteobacteria & Arctic and Antarctic sea ice & -40.6 \\
\hline 11B5 & Shewanella frigidimarina & $\gamma$-Proteobacteria & Arctic and Antarctic sea ice & $-41.1 \pm 0.8$ \\
\hline $37 \mathrm{P}$ & Psychromonas ingrahamii str. $37 P$ & $\gamma$-Proteobacteria & Arctic sea ice & -42.7 \\
\hline $4 \mathrm{U} 1$ & Cytophaga sp. JTB 244 & $\mathrm{CFB}^{* *}$ & Arctic sea ice, Japan Trench & -41.7 \\
\hline 4M6 & marine psychrophile SW $17^{\mathrm{a}}$ & $\mathrm{CFB}$ & Arctic sea ice, Antarctic seawater & $-41.3 \pm 0.9$ \\
\hline $4 \mathrm{M} 7$ & Flavobacterium xanthum & CFB & Arctic and Antarctic sea ice & $-41.0 \pm 0.4$ \\
\hline $6 \mathrm{~B} 2$ & Polaribacter franzmannii & CFB & Arctic and Antarctic sea ice & $-41.3 \pm 0.6$ \\
\hline 4B3 & Octadecabacter antarcticus & $\alpha$-Proteobacteria & Arctic and Antarctic sea ice & $-41.4 \pm 0.5$ \\
\hline $\mathrm{S} 23 \mathrm{~F} 1$ & Planomicrobium mcmeekenii & Low-GC Gram-positives & Antarctic sea ice & -41.4 \\
\hline Virus & Colwellia infecting phage $\mathrm{V} 9$ & & Arctic sediment, Antarctic sea ice & $-41.9^{c}$ \\
\hline $\mathrm{R} 31$ & Pseudomonas syringae & $\gamma$-Proteobacteria & terrestrial, plant leaves & $-6.3^{\mathrm{d}}$ \\
\hline ASW & Artificial seawater & & & $-42.2 \pm 0.3$ \\
\hline $\mathrm{H}_{2} \mathrm{O}$ & pure HPLC water & & & -37 \\
\hline PHB & Phage Buffer & & & -42.5 \\
\hline
\end{tabular}

* Average + /- standard deviation $(n=2$, for ASW $n=4)$.

** CFB is Cytophaga-Flavobacteria-Bacteroides.

a Closest genus was Alteromonas.

b Closest genus was Gelidibacter.

c Virus in buffer at approx $10^{9}$ particles $^{*} \mathrm{ml}^{-1}$.

$\mathrm{d}$ Bacteria in pure HPLC water at optical density of 2.0 at $600 \mathrm{~nm}$.

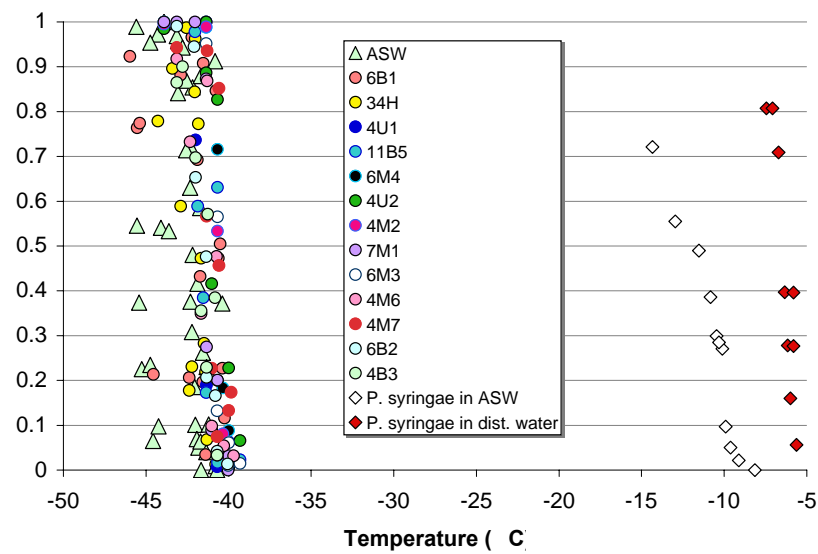

Fig. 3. Freezing spectra for ASW (triangles), representative seaice bacteria (circles, different colours indicate different strains) in comparison with P.syringae (diamonds: red, cells in HPLC-grade water; white, cells in ASW).

temperature where $\mathrm{F}(\mathrm{T})=50 \%$. Our tests revealed that sea-ice isolates and phage virus particles nucleated ice at temperatures very close to the homogeneous nucleation tempera- ture for the nucleation medium ( $T_{f}$ for ASW: $-42.2 \pm 0.3^{\circ} \mathrm{C}$, see Table 1 ). Thus, the average $T_{f}$ ( \pm standard deviation) for the psychro-active bacterial isolates was found to be $41.3 \pm 0.6^{\circ} \mathrm{C}$ (range -40.4 to $-42.7^{\circ} \mathrm{C}, n=15$ ). For $P$. $s y$ ringae str. R31 suspended in distilled water at $\mathrm{OD}$ of 2.0 , we found ice nucleation temperatures that are in good agreement with published values $\left(T_{f}=-6.3^{\circ} \mathrm{C}\right.$, Lindow, 1985). However, when P.syringae str. R31 cells were suspended in ASW at the same OD, ice nucleation temperatures dropped significantly with a $T_{f}$ of $-11.7^{\circ} \mathrm{C}$ indicating a profound effect of the freezing medium on ice nucleation temperatures.

These results suggest that the sea-ice bacteria and viruses tested here have a very limited ice nucleation activity. Our finding stands in contrast to earlier suggestions that such bacteria and/or viruses are involved in polar cloud precipitation processes (Bigg and Leck, 2001). We tested these organisms since they were found to be the numerically dominant members of the Arctic sea-ice bacterial community (see Junge et al., 2001 for a detailed explanation on how this was determined). More recent studies have also confirmed the predominance of the same groups and genera both in Arctic and Antarctic sea-ice samples (see Brinkmeyer et al., 2003). Nevertheless, it is entirely possible that other strains (even of 
the same genera, such is the case with E. herbicola, where some strains show high INA and others not, Steve Lindow, personal communication) could be ice nucleation active. In case of the bacteriophage V9, there is no information available on the prevalence of this (or other cold-active) viruses in the Arctic (see Wells, 2007 for an in-depth review on coldactive viruses). V9 is of particular interest though since it represents one of the few cold-active viruses that have been characterized in detail. Furthermore, to our knowledge, the ice nucleation behavior of viruses (temperate, warm or coldactive) has only rarely been tested in general. Other species, however, derived from other sources, such as vegetation derived $P$. syringae, or other INA Pseudomans species, as described to occur in the Arctic atmosphere (Jayaweera and Flanagan, 1982) and/or P. antarctica, derived from Antarctic soil (Obota et al., 1999) or Antarctic lake bacteria (Gilbert et al., 2004) could provide alternative sources for ice forming nuclei in the atmosphere, but direct (in situ) evidence for this activity and bacterial activity in the atmosphere in general remains to be demonstrated (for review see Szyrmer and Zawadski, 1997; Möhler et al., 2007). Obtaining such knowledge is especially important as metabolic activity and intact proteins of the outer membrane appear to be required for effective ice nucleating property (Hazra et al., 2004).

So what role do bacteria play in the polar atmosphere? Knowledge of bacterial diversity and activity in the atmosphere is scarce, especially for the Polar region (Carpenter et al., 2000; Posfai et al., 2003; Amato et al., 2007; Elster et al., 2007) and has recently become of greater research interest (see references in Sattler et al., 2001; Bauer et al., 2002, Ahern et al., 2006; Möhler et al., 2007; Christner et al., 2008). In Antarctica, devoid of a terrestrial source for ice nuclei (IN), studies suggest that biological nuclei play a role in the formation of coastal clouds and that the ocean surface might be their source (Saxena, 1983). Schnell (1975) proposed that marine organisms may be responsible for the bands of airborne ice nucleation activity found along latitudes of $40^{\circ}$ and $55^{\circ}$ South by Bigg (1973). Schnell and Vali (1976) found that seawater collected in Bedford Basin, Nova Scotia were good sources of IN when they contained phytoplankton with some IN active at $-4^{\circ} \mathrm{C}$. Our findings are in stark contrast to these results and this could be due to two causes: Substrate-based methods for measuring low-temperature INA can be problematic if substrates are not sufficiently well passivated (typically by the application of a surface coating like organosilane) to reduce the possibility of heterogeneous nucleation initiated by the surface.

The freezing tube method has been tested by measuring the homogeneous ice nucleation temperature of aqueous sulfuric acid and ammonium sulfate solutions (Larson and Swanson, 2006 and Swanson, 2008). Considerable effort has been made to reduce to near zero (by sample filtration and flushing sample dispensers and the freezing tube etc.) the probability of the occurrence of other heterogeneous processes. Sample droplets are not in contact with substrates in this method and the lower temperature limit (about $-65^{\circ} \mathrm{C}$ ) is set by the cooling capacity of the cryogenic bath unit. To check this method, the homogeneous freezing temperature of pure water was measured to be $-37^{\circ} \mathrm{C}$ - which is consistent with previous experiments (see Wood et al., 2002). We considered marine psychrophiles to be good candidates for hightemperature INA, since they are abundant in polar waters and sea-ice but seawater samples also contain other potential IN such as phytoplankton, fungi, dust, salts etc. Thus the lowtemperature INA observed for our sea-ice bacterial isolates would be masked by the presence of higher-temperature IN in, for instance, seawater samples. Perhaps other IN referred to as ocean-derived nuclei (ODN) are responsible for the nucleation observed by Schnell and Vali (1976). The transfer of materials from the oceans to the atmosphere is well documented (Schnell and Vali, 1976). These materials, when lifted into the air in regions of an active sea-to-air transfer mechanism (demonstrated to occur through the bursting of bubbles (Schnell and Vali, 1976; Szyrmer and Zawadzki, 1997), could cause ice nucleation and thus affect polar cloud precipitation processes. It should be noted though that, except for the ODN described by Schnell and Vali (1976), the world oceans have not been found to be a source of IN with many studies demonstrating that maritime air masses are consistently deficient in IN (Pruppacher and Klett, 1997). Future experiments will explore other materials and additional sea-ice bacterial isolates to identify the species responsible for the observed higher-temperature INA. Furthermore, although we've found that the sea-ice bacteria studied do not induce ice nucleation via immersion freezing at higher temperatures, there are two other modes of ice nucleation in which they still could be tropospherically active. They could be good contact mode nuclei or condensation mode nuclei (Pruppacher and Klett, 1997). Additional experiments are warranted to explore these possibilities further.

The limited polar bacterial ice nucleation activity documented here adds to evidence of undetectable bacterial ice nucleation activity found by others in cloud and rain samples collected from Scottish mountains tops (Ahern et al., 2006). Using culture-independent molecular methods, Ahern et al. (2006) determined that cloud bacteria were closely related to bacteria from other cold environments and were dominated by a mixture of fluorescent Pseudomonas spp. (thought to be efficient ice nucleators), though with no detectable ice nucleation genes. Instead the majority of isolates displayed significant biosurfactant activity. Though it is too early to draw general conclusions based on only two studies, these findings cause us to formulate the hypothesis that the majority of airborne bacteria are not ice nucleation active but rather attract available liquid water sources (by producing exopolymeric substances (EPS) as many sea-ice bacteria (Krembs et al., 2002) or biosurfactants and thus becoming cloud condensation nuclei (CCN) active (as demonstrated by Bauer et al., 2002 and Ahern et al., 2006). This would allow for water scavenging, countering desiccation, and assist 
in their widespread dispersal (Ahern et al., 2006). In other non-polar regions, bacterial ice nucleation activity has been so far extensively investigated only in terrestrial plant bacteria such as Pseudomonas syringae (see for review Lee et al., 1995). There is no clear evidence however that they play a role in the formation of ice in clouds (for review see Möhler et al., 2007). Plant-derived bacteria have been observed in the atmosphere above plant canopies at heights up to $6 \mathrm{~km}$ (Lindemann et al., 1982; Lindemann and Upper, 1985) and in raindrops, hailstones both in North America, Europe, Asia and the Arctic (Lindow et al., 1978; Yankofsky et al., 1981; Jayaweera and Flanagan, 1982), however, attempts to obtain typical marine microorganisms with INA have not been met with success, with the exception of one INA bacterial strain phenotypically very similar to Pseudomonas fluorescens isolated from a marine dinoflagellate culture (Fall and Schnell, 1985).

Our results indicate that the IN in this population have an INA too low to be involved with sea-ice formation. An earlier study that showed one sea-ice strain (to date still unidentified) to have INA at higher temperatures that suggested such a possible role of sea-ice bacteria (Parker et al., 1985) could not be substantiated using our novel technique and analyzing representatives of most major groups of sea-ice bacteria. Our results though expand and corroborate earlier findings of others who failed to find significant INA in the majority of marine (but not polar) bacteria that were studied (Fall and Schnell, 1985). The present study thus substantiates these earlier observations that were limited because (1) they investigated only a small number of droplets $(<100$ droplets as opposed to an average of 1000 droplets as in the present study) and (2) they used substrate-based freezing methodologies.

Ice is ubiquitous, not only on Earth, but also in our solar system. Our examination of the freezing behavior of polar ice bacteria revealed how these bacteria might cope with freezing temperatures and the ice itself - by largely avoiding ice nucleation and thereby remaining within liquid water, essential prerequisite to maintain active growth. Sea ice is the coldest marine habitat on Earth and the mechanism for survival of polar marine bacteria during cold and salty conditions are of considerable interest. Sea-ice liquid brine temperatures can reach as low as $-35^{\circ} \mathrm{C}$ with corresponding in situ salinities of $240 \mathrm{ppt}$ (Cox and Weeks, 1983; Maykut, 1986). These conditions are known to select for psychrophiles (Helmke and Weyland, 1995 and 2004; Bowman et al., 1997; Nichols et al., 1999; Bowman et al., 2005) and sea-ice bacteria are model organisms to study polar marine psychrophily. Such bacteria have been shown to be active in their environment down to $-20^{\circ} \mathrm{C}$ and 209 ppt (Junge et al., 2004 and possibly even much lower [to $-196^{\circ} \mathrm{C}$ ] see Junge et al., 2006) and have developed strategies to overcome detrimental effects of very cold temperatures well-known for a wide range of bacterial processes (for a review see Deming, 2002). Much published research on sea-ice organisms has focused on their diversity (reviewed by Bowman et al., 2005), enzyme and membrane adaptations (reviewed by Nichols et al., 1999; Deming, 2002) and field observations of sea-ice microbial communities (e.g. Helmke and Weyland, 1995; Junge et al., 2004). During the freezing processes itself the majority of bacteria apparently remain within liquid brine pockets within the ice matrix (Junge et al., 2001) possibly by reducing the close proximity of ice to the outer cell wall during the passing of a freezing front. Survival during ice crystal formation or once encased in sea ice certainly also involves the avoidance of ice crystal formation within their cells (Deming, 2002; D'Amico et al., 2006). Having limited ice nucleation activity could be a bacterial strategy for avoiding direct attachment to ice and thus also reducing the likelihood of ice crystal formation within their cells.

To determine if our interpretations are correct and the freeze-avoidance found for sea-ice bacteria is indeed a form of special adaptation to an icy environment, it is crucial to study the freezing behavior of additional non-INA mesophilic bacteria. We are not aware of studies of non icenucleation active bacteria under similar experimental conditions (i.e. ultra-pure and substrate free) and so additional bacteria need to be tested to evaluate the significance of our results with respect to sea-ice bacterial adaptation and also atmospheric ice formation processes. As such, this study represents the starting point for further investigations of the range of polar bacterial ice nucleation temperatures under conditions resembling more closely those that are present in the atmosphere. For instance, initial single-run low resolution freezing spectrum of Pseudomonas antarctica showed freezing temperatures ranging from about -20 to $-40^{\circ} \mathrm{C}$ in artificial seawater (unpublished results). These initial findings need to be verified, but if proven correct, it indicates that this bacterium contains compounds referring INA over a very broad range of temperatures previously not found for bacteria (and which were possibly undetectable with substrate-based methods, see Obata et al., 1999). Currently, we are exploring this further (in addition to testing other mesophilic isolates, such as INA-plus and INA-minus strains of Erwinia herbicola). The freeze tube results from Pseudomonas syringae indicated a significant change in nucleation activity as a result of a change in freezing medium (from distilled to artificial seawater). Though the explanation for this remains speculative at the moment (i.e. perhaps the exposure to the salt in ASW preferentially affects the higher temperature nucleating membrane INA proteins and is related to the process by which salt acts as a biocide for this bacteria), we plan to study the freezing behavior of sea-ice bacteria also in pure water, since one can imagine an atmospheric scenario where marine polar bacteria as part of the aerosol would act as CCN and form freshwater liquid water droplets that then could nucleate to ice. 
The apparent avoidance of INA raised the following question: Do sea-ice bacteria exhibit special ice preventative surface structures such that they largely avoid the ice initiation that other solid objects of their size would experience? An examination of the surface of some of our sea-ice isolates using surface-enhanced Raman-spectroscopy techniques (Laucks et al., 2005) indicated that compared to other gram-negative mesophilic bacteria psychro-active isolates do possess unique surface structures, likely represented by their different membrane fatty acid composition. Within the seaice environment, our results suggest that sea-ice bacteria as they represent ice-forming nuclei with INA at sufficiently low temperatures will largely avoid ice formation around their cells. Thus they remain in their liquid brine environment (as opposed to being frozen directly into the solid ice) with nutrient exchange and metabolic activity possible to the lowest subzero temperatures encountered there $\left(-35^{\circ} \mathrm{C}\right)$.

\section{Summary}

We have used the freezing tube methodology to observe the INA of sea-ice bacteria isolates away from the possible effects of substrates. Studying INA away from substrate surfaces is critical since prior to this study, most bacterial ice nucleation studies have been performed on solid surfaces (with a few exceptions, Möhler et al., 2007). We find lowtemperature INA for the isolates observed in this study and these isolates are therefore not likely to be important as ice nucleation agents through immersion freezing processes in the polar atmosphere. Overall, knowledge of bacterial diversity and activity is essential to predict potential bacterial impact not only on glaciated cloud formation processes but also on air chemistry if metabolically active bacteria process organic and inorganic species of importance for atmospheric processes (Ariya and Amyot, 2004). We conclude that the degree of ice nucleation activity derived through bacteria in polar clouds (either limited ice nucleation activity [e.g. by sea-ice bacteria] or high ice nucleation activity (e.g. by $P$. syringae or $P$. antarctica - type bacteria) will depend on the bacterial species composition (diversity) and bacterial activity in the atmosphere.

Acknowledgements. This research was supported by awards from the NSF OPP program to B. Swanson and K. Junge (NSF Grant OPP-0338333) and from the NSF ATM program to B. Swanson (NSF Grant ATM-0323930). We are very grateful to J. Deming for allowing us to use her laboratory facilities to culture bacterial test strains. We thank B. Wearn and T. Harrit for their assistance in conducting INA measurements and data analysis; and L. Wells for providing the Colwellia phage preparations for virus INA tests.

Edited by: J.-P. Gattuso

\section{References}

Ahern, H. E., Walsh, K. A., Hill, T. C. J., and Moffett, B. F.: Ice-nucleation negative fluorescent pseudomonads isolated from Hebridean cloud and rain water produce biosurfactants, Biogeosciences Discuss., 3, 1561-1586, 2006, http://www.biogeosciences-discuss.net/3/1561/2006/.

Amato, P., Hennebelle, R., Magand, O., Sancelme, M., Delort, A.M., Barbante, C., Boutron, C., and Ferrari, C.: Bacterial characterization of the snowcover at Spitzberg, Svalbard, FEMS Microbiol. Ecol., 59, 255-264., 2007.

Ariya, P. A. and Amyot, M.: New Directions: The role of bioaerosols in atmospheric chemistry and physics, Atmos. Environ., 38, 1231-1232, 2004.

Bauer, H., Kasper-Giebl, A., Loflund, M., Giebl, H., Hitzenberger, R., Zibuschka, F., and Puxbaum, H.: The contribution of bacteria and fungal spores to the organic carbon content of cloud water, precipitation and aerosols, Atmos. Res., 64, 109-119, 2002.

Bauer, H., Giebl, H., Hitzenberger, R., Kasper-Giebl, A., Reischl, G., Zibuschka, F., and Puxbaum, H.: Airborne bacteria as cloud condensation nuclei, J. Geophys. Res., 108, 4658, 2003.

Bigg, E. K.: Ice nucleus measurements in remote areas, J. Atmos. Sci., 30, 1153-1157, 1973.

Bigg, E. K. and Leck, C.: Cloud-active particles over the central Arctic Ocean, J. Geophys. Res., 106, 32155-32166, 2001.

Bowman, J. P., McCammon, S. A., Brown, M. V., Nichols, D. S., and McMeekin, T. A.: Diversity and association of psychrophilic bacteria in Antarctic sea ice, Appl. Environ. Microbiol., 63, 3068-3078, 1997.

Bowman, J. P., Gosink, J. J., McCammon, S. A., Lewis, T. E., Nichols, D. S., Nichols, P. D., Skerrat, J. H., Staley, J. T., and McMeekin, T. A.: Colwellia demingae sp. nov., Colwellia hornerae sp. nov., Colwellia rossensis sp. nov. and Colwellia psychrotropica sp. nov.: psychrophilic Antarctic species with the ability to synthesize docohexaenoic acid (22:6 n-3), Int. J. Syst. Bacteriol., 48, 1171-1180, 1998.

Bowman, J. P., Abell, G. C., Mancuso Nichols, C. A.: Psychrophilic Extremophiles from Antarctica: Biodiversity and biotechnological potential, Ocean and Polar Res., 27, 221-230, 2005.

Brinkmeyer, R., Knittel, K., Jürgens, J., Weyland, H., Amann, R., and Helmke, E.: Diversity and structure of bacterial communities in Arctic versus Antarctic pack ice, Appl Environ Microbiol, Nov, 69(11), 6610-6619, 2003.

Carpenter, R. E., Lin, S., and Capone, D. G.: Bacterial activity in South Pole snow, Appl. Environ. Microbiol., 66, 4514-4517, 2000.

Cavicchioli, R.: Cold-adapted archaea, Nature Rev. Microbio., 4, 331-343, 2006.

Christner, B. C., Morris, C. E., Foreman, C. M., Cai, R., and Sands,D. C.: Ubiquity of biological ice nucleators in snowfall, Science, 319, 1214, 2008.

Cox, G. F. N. and Weeks, W. F.: Equations for determining the gas and brine volumes in sea-ice samples, J. Glaciol., 29, 306-316, 1983.

D’Amico, S., Collins, T., Marx, J.-C., Feller, G., and Gerday, C.: Psychrophilic microorganisms: challenges for life, EMBO reports 7, 385-389, 2006.

Deming, J. W.: Psychrophiles and polar regions, Curr. Opin. Microbiol., 3, 301-309, 2002.

Eicken, H., and Lemke, P.: The response of polar sea ice to cli- 
mate variability and change, in: Lozán et al., Climate of the 21 st century, Changes and risks, GEO, Hamburg/Germany, 206-211, 2001

Elster J., Delmas, R. J., Petit, J.-R., and eháková, K.: Composition of microbial communities in aerosol, snow and ice samples from remote glaciated areas, (Antarctica, Alps, Andes), Biogeosciences Discuss., 4, 1779-1813, 2007, http://www.biogeosciences-discuss.net/4/1779/2007/.

Fall, R. and Schnell, R. C.: Association of an ice nucleation pseudomonad with cultures of marine dinoflagellate Heterocapa niei, J. Mar. Res., 43, 257-265, 1985.

Gilbert, J. A., Hill, P. J., Dodd, C. E. R., and Laybourn-Parry, J.: Demonstration of antifreeze protein activity in Antarctic lake bacteria, Microbio., 150, 171-180, 2004.

Hazra, A., Saha, M., De, U. K., Mukherjee, J., and Goswami, K.: Study of ice nucleating characteristics of Pseudomonas aeruginosa, Aerosol Sci., 35, 1405-1414, 2004.

Helmke, E. and Weyland, H.: Bacteria in sea ice and underlying water of the eastern Weddell Sea in midwinter, Mar. Ecol. Prog. Ser., 117, 269-287, 1995.

Helmke, E. and Weyland, H.: Psychrophilic versus psychrotolerant bacteria-occurrence and significance in polar and temperate marine habitats, Cell Mol Biol., 50, 553-561, 2004

Huston, A. L., Krieger-Brockett, B. B., and Deming, J. W.: Remarkably low temperature optima for extracellular enzyme activity from Arctic bacteria and sea ice, Environ. Microbiol., 2, 383-388, 2000.

Houghton, J. T., Ding, Y., Griggs, D. J., Noguer, M., van der Linden, P. J., Dai, X., Maskell K., and Johnson, C. A.: IPCC, Climate change 2001: Third assessment report of the Intergovernmental Panel on Climate Change (IPCC), Cambridge University Press, Cambridge, 2001.

Jayaweera, K. O. L. F. and Flanagan, P.: Biogenic ice nuclei in the Arctic atmosphere, Geophys. Res. Lett., 9, 94-97, 1982.

Junge, K., Eicken, H., Swanson, B. D., and Deming, J. W.: Bacterial incorporation of leucine into protein down to $-20^{\circ} \mathrm{C}$ with evidence for potential activity in subeutectic saline ice formations, Cryobiol. 52, 417-429, 2006.

Junge, K., Eicken, H., and Deming, J. W.: Bacterial activity at -2 to $-20^{\circ} \mathrm{C}$ in arctic wintertime sea ice, Appl. Envir. Microbiol., 70, $550-555,2004$.

Junge, K., Imhoff, J. F., Staley, J T., and Deming, J. W.: Phylogenetic diversity of numerically important arctic sea-ice bacteria cultured at subzero temperature, Microb. Ecol., 43, 315-328, 2002.

Junge, K., Krembs, C., Deming, J., Stierle, A., and Eicken, H.: A microscopic approach to investigate bacteria under in situ conditions in sea-ice samples, Ann. Glaciol., 33, 304-310, 2001.

Junge K., Gosink, J. J., Hoppe, H.-G., and Staley, J. T.: Arthrobacter, Brachybacterium and Planococcus isolates identified from Antarctic sea ice brine, Description of Planococcus mcmeekenii, sp. nov. Syst Appl Microbiol, 21, 306-314, 1998.

Laucks, M. L., Sengupta, A., Junge, K., Davis, E. J., and Swanson, B. D.: Comparison of psychro-active Arctic marine bacteria and common mesophilic bacteria using surface-enhanced Raman spectroscopy, Appl. Spectroscopy, 10, 1222-1228, 2005.

Larson, B. H. and Swanson, B. D.: Experimental investigation of the homogeneous freezing of aqueous ammonium sulfate droplets, J. Phys. Chem. A., 110, 1907-1916, 2006.
Leck, C. and Bigg, E.K.: Aerosol production over remote marine areas - a new route, Geophys. Res. Lett., 26, 3577-3580, 1999.

Lee, R. E., Warren, G. J., and Gusta, L. V.: Biological ice nuclation and its applications, APS Press; The American Phytopathological Society, St. Paul, Minnesota, 1995.

Levin, Z. and Yankofsky, S. A.: Contact versus immersion freezing of freely suspended droplets by bacterial ice nuclei, J. Appl. Meteorol., 22, 1964-1966. 1983.

Lindemann, J. and Upper, C. D.: Aerial dispersal of epiphytic bacteria over bean plants, Appl. Environ. Microbiol., 50, 1229-1232, 1985.

Lindemann, J., Constantinidou, H. A., Barchet, W. R., and Upper, C. D.: Plants as sources of airborne bacteria including ice nucleation active bacteria, Appl. Environ. Microbiol., 44, 1059-1063, 1982.

Lindow, S. E.: Membrane fluidity as a factor in production and stability of bacterial ice nuclei active at high subfreezing temperatures, Cryobiol., 32, 247-258. 1995.

Lindow, S. E., Arny, D. C., Upper, C. D., and Barchet, W. R.: In: The role of bacterial ice nuclei in frost injury to sensitive plants edited by: Li, P. H. and Sakai, A., Plant Cold-Hardiness and Freezing Stress, vol. 1, Academic Press, 249-263, 1978.

Möhler, O., DeMott, P. J., Vali, G., and Levin, Z.: Microbiology and atmospheric processes: the role of biological particles in cloud physics, Biogeosciences Discuss., 4, 2559-2591, 2007, http://www.biogeosciences-discuss.net/4/2559/2007/.

Nichols, D., Bowman, J., Sanderson, K., Nichols, C. M., Lewis, T., McMeekin, T., and, Nichols, P. D.: Developments with Antarctic microorganisms: culture collections, bioactivity screening, taxonomy, PUFA production and cold-adapted enzymes, Curr. Opin. Biotechnol, 10, 240-246, 1999.

Obata, H., Muryoi, N., Kawahara, H., Yamade, K., and Nishikawa, J.: Identification of a novel ice-nucleating bacterium of Anarctic origin and its nucleation properties, Cryobiol., 38, 131-139. 1999.

Parker, L. V., Sullivan, C. W., Forest, T. W., and Ackley, S. F.: Ice nucleation activity of Antarctic marine microorganisms, Antarctic J., 20, 126-127, 1985.

Posfai, M., Li, J., Anderson, J. R., and Buseck, P. R.: Aerosol bacteria over the Southern Ocean during ACE-1, Atmospheric Res., 66, 231-240, 2003

Pruppacher, H. R. and Klett, J. D.: Microphysics of clouds and precipitation, Springer-Verlag, 954 pp., 1997.

Sattler, B., Puxbaum, H., and Psenner, R.: Bacteria growth in supercooled clouds, Geophys. Res. Lett., 28, 239-242, 2001.

Saxena, V. K.: Evidence of the biogenic nuclei involvement in Antarctic coastal clouds, J. Phys. Chem., 87, 4130-4134, 1983.

Schnell, R. C.: Ice nuclei produced by laboratory cultured marine phytoplancton, Geophys. Res. Lett., 2, 500-502, 1975.

Schnell, R. C. and Vali, G.: Biogenic ice nuclei: Part I. Terrestrial and marine sources, J. Atmos. Sci., 33, 1554-1564, 1976.

Sullivan, C. W.: Sea ice bacteria: reciprocal interactions of the organisms and their environment. in: Sea Ice Biota, edited by: Horner, R. A, by CRC Press, Boca Raton, Florida, 22-79, 1985.

Swanson, B. D.: How well does water activity determine homogeneous ice nucleation in aqueous sulfuric acid and ammonium sulfate droplets?, J. Atmos. Sci., accepted, 2008.

Szyrmer, W. and Zawadzki, I.: Biogenic and anthropgenic sources of ice-forming nuclei: a review, Bull. Amer. Meteor. Soc., 78, 
209-228, 1997.

Vogelmann, A. M. and Ackerman, T. P.: Relating cirrus cloud properties to observed fluxes: a critical assessment, J. Atmos. Sci., 52, 4285-4301, 1995.

Wells, L. E. and Deming, J. W.: Characterization of a cold-active bacteriophage on two psychrophilic marine hosts, Aquat. Microb. Ecol., 45, 15-29, 2006.

Wells, L.: Cold-active viruses, in: psychrophiles: from biodiversity to biotechnology, edited by: Margesin, R., Schinner, F., Marx, J.-C., and Gerday, C., Springer-Verlag, Berlin. Chapter 10, 157$173,2007$.
Wood, S. E., Baker, M. B., and Swanson, B. D.: New instrument for studies of homogeneous and heterogeneous ice nucleation in free-falling supercooled water droplets, Rev. Sci. Inst., 73, 39883996, 2002.

Yankofsky, S. A., Levin, Z., Bertold, T., and Sandlerman, N.: Some basic characteristics of bacterial freezing nuclei, J. Appl. Meteor., 20, 1013-1019, 1981. 